American Journal of Environmental Sciences 7 (5): 415-422, 2011

ISSN 1553-345X

(C) 2011 Science Publications

\title{
Annual Concentration Report and Emission Sources Analysis of the Air Pollutants Measured by the Air Quality Monitoring Station
}

\author{
${ }^{1}$ P. Khaenamkaew, ${ }^{1}$ S.Raksawong, ${ }^{2}$ K.Wongsorntam, \\ ${ }^{2}$ S. Khuntong, ${ }^{3} \mathrm{P}$. Iamraksa and ${ }^{4} \mathrm{~T}$. Wutikhun \\ ${ }^{1}$ Department of Basic Sciences and Physical Education, \\ ${ }^{2}$ Department of Environmental Science, \\ Faculty of Resources and Environment, \\ ${ }^{3}$ International Maritime College, \\ Kasetsart University, Si Racha Campus, Chonburi, 20230, Thailand \\ ${ }^{4}$ Development National Science and Technology Agency, \\ 111, Thailand Science Park, Phahonyothin Road, \\ Klong Luang, Phathumthani, 12120, Thailand
}

\begin{abstract}
Problem statement: Air Quality Monitoring (AQM) station at Kasetsart University, Si Racha Campus, Thailand, was routinely monitor the annual concentrations and analysis the emission sources of the air pollutants in the area since 2007. The level of concentration $\mathrm{CO}, \mathrm{SO}_{2}, \mathrm{NO}_{\mathrm{x}}$ and $\mathrm{O}_{3}$ were measured. $\mathrm{PM}_{10}$ concentration was measured by mean of TOEM method. The $\mathrm{PM}_{10}$ and TSP (manifold) filters were collected for the measurement of heavy metals adsorbed in the particulate by ICP-AES techniques. Scanning Electron Microscopic (SEM) and Energy Dispersive Spectrometric (EDS) techniques were used to identify the morphologies and elemental compositions of particulate matters from the $\mathrm{PM}_{10}$ and TSP filters. Approach: The annual concentrations of all pollutants were almost real-time reported from July 2007-2008. The $\mathrm{O}_{3}$ concentrations are higher than the standard level (100 ppb) in July 2007 and April 2008 with the value of 109 and $114 \mathrm{ppb}$, respectively. Average $\mathrm{PM}_{10}$ concentrations are higher than the standard level $\left(120 \mu \mathrm{g} . \mathrm{m}^{-3}\right)$ in November 2007, January 2008 and March 2008 with the value of 129, 123 and 125 $\mu \mathrm{g} . \mathrm{m}^{-3}$, respectively. Strong correlations between $\mathrm{NO}_{2}$ with $\mathrm{O}_{3}$ and between $\mathrm{NO}_{2}$ with $\mathrm{PM}_{10}$ were found. Results: These results showed that $\mathrm{NO}_{2}$ was the precursor of the photochemical reaction and generate $\mathrm{O}_{3}$. $\mathrm{NO}_{2}$ concentrations are found to be corresponding with both $\mathrm{O}_{3}$ and $\mathrm{PM}_{10}$. The directions of $\mathrm{O}_{3}$ emission sources were the southwest, south and southeast due to wind direction, whereas the $\mathrm{PM}_{10}$ are originated from the northwest. The microscopic structures of TSP provided various shapes and dimensions from 0.1 to greater than $100 \mu \mathrm{m}$, while the microstructures of $\mathrm{PM}_{10}$ presented the needle-like and spherical shape. SEMEDS analysis was able to detect some element (C, O, F, Na, Al, Si and K), while the ICP-AES showed that there were other heavy metals present in the filter sample ( $\mathrm{Ni}, \mathrm{Cu}, \mathrm{Zn}, \mathrm{Pb}$ and $\mathrm{Se})$. Conclusion: Among the amounts of selected heavy metals, $\mathrm{Zn}$ is the most probable among all metals with the value of $1.3891 \pm 1.6198 \mu \mathrm{g} . \mathrm{g}^{-1} \cdot \mathrm{m}^{-3}$ in TSP. Amounts of heavy metals inPM $\mathrm{M}_{10}, \mathrm{Cu}$ is dominated with $0.5374 \pm 0.8084$ $\mu \mathrm{g} . \mathrm{g}^{-1} \cdot \mathrm{m}^{-3}$, the others were almost in the same levels and much lower than in TSP. Correlation coefficient between each metal can be estimate the emission source of their particulate matter together with the wind speed and wind direction.
\end{abstract}

Keywords: Air quality monitoring, Si Racha, heavy metal, Scanning Electron Microscopic (SEM), heavy metals, emission sources, spherical shape, wind direction, elemental compositions

\section{INTRODUCTION}

Air Quality Monitoring (AQM) station at the Kasetsart University, Si Racha campus, Chonburi,
Thailand was established since 2007. AQM station plays an important role in monitoring the situation of air pollution around industrial areas such as $\mathrm{Si}$ Racha and LaemChabung industrial estate, where the Si RachaTown

Corresponding Author: P. Khaenamkaew, Department of Basic Sciences and Physical Education, Faculty of Resources and Environment, Kasetsart University, Si Racha Campus, Chonburi, 20230, Thailand, Tel.: +66 50933013 Fax:+66 38354587 
Municipal and LaemChabung City Municipal have received the complaining about the air pollution more than 100 times since 2006 (OSOS, 2009).

Air pollution is the serious problems around the world, especially in less-industrialized countries where the early stages of industrial growth are often pursued without much investment in environmental protection, leading to heavy air pollution in urban areas (Florig et al., 2002). In many developing countries including Thailand one factor related to atmospheric pollution originated from urban contribution where is directly resulted of uncontrolled emission from motor vehicular and other anthropogenic activities (Kim and Hopke, 2008).

Si Racha Metropolitan Area (SRMA), Chonburi province is located at the east of Thailand. The major sources of air particulate include transportation, stationary fuel combustion, processes and agricultural waste and others. From Si Racha Public Health records, population in Si Racha got sick in the respiratory syndrome 21 cases (diseases of respiratory system). The numbers of patients were 46163, $56593,65139,59030$ and 58016 in the year of 2005, 2006, 2007, 2008 and 2009, respectively Report Sheet 504.

Up to now, the concentration levels of air pollutants in the area are routinely monitored by the Pollution Control Department (PCD) Ministry of Natural Resources and Environment. Air quality was monitored using a standard method for ambient air pollution. Although 53 AQM stations are distributed aroundthe whole country, only 4 stations are located in the industrial area, Chonburi province. The results of pollutant annual concentration from PCD are very close to the limit level of the (Notification of National Environmental Board No. 28, B.E. 2007, Table 1) (CD, 2010). These levels may cause high risk on population health in the area. Particularly, particulate matters can cause coughing, wheezing and overall decreased lung function in children and adult (Zanobetti et al., 2000; Limbach et al., 2005).

Table 1: Standard level concentrations of each pollutant (DEQM,

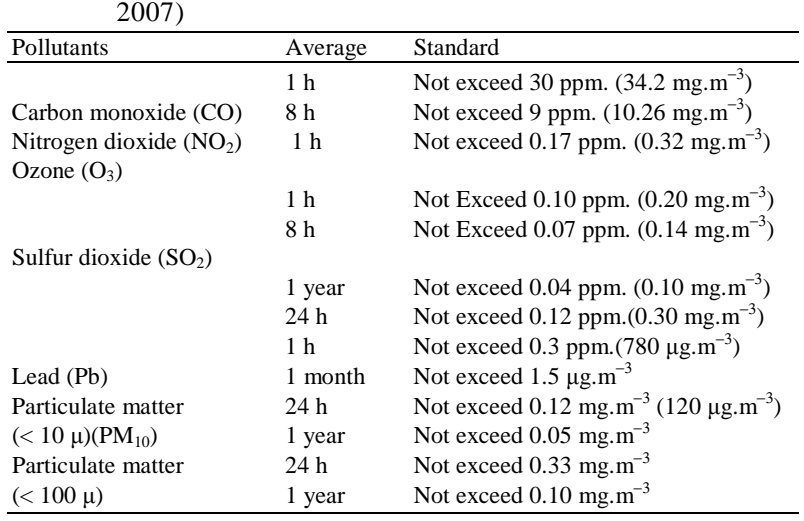

However, it is very important to characterize airborne particulate matters especially morphology, chemical compositions and their origins in relation to health and environmental impact (Baulig et al., 2004; Areekijseree et al., 2009). It is very important to measure not only the levels of fine particles in and around major cities and industrial area but also to identify the sources of these particles.

The aims of this research are: (1) To quantify the average concentrations of $\mathrm{CO}, \mathrm{SO}_{2}, \mathrm{NO}_{\mathrm{x}}, \mathrm{O}_{3}, \mathrm{PM}_{10}$ and TSP in ambient air around $\mathrm{Si}$ Racha area. (2) To measure the heavy metal accumulated in the particulate matter, elemental composition and microstructure of $\mathrm{PM}_{10}$ and TSP (3) To identify the possible emission sources of the air pollutants with the meteorological data. Identifying the source of airborne particles and their composition, physical and chemical properties will help to provide a clear connection to their impact on the environment and the human health (Brook et al., 2004).

\section{MATERIAL AND METHODS}

Sampling location: The Si Racha Metropolitan Area has a surface area of approximately $616.4 \mathrm{~km}^{2}$ and about 228,717inhabitants. The atmospheric aerosol has been studied since 2006 (Pollution Control Department (PCD). There are basically three seasons in SRMA: a rainy (June to August), a winter and dry (November to February) and a summer (March to May) season. The air quality monitoring is located in Kasetsart University Si Racha Campus $\left(13^{\circ} 07^{\prime} 15.42^{\prime \prime} \mathrm{N}, 100^{\circ} 55^{\prime} 09.28^{\prime} \mathrm{E}\right)$ where is about $15 \mathrm{~m}$ closed to Sukumvit Road (Fig. 1ac). The station unit is situated within an urban commercial/residential and industrial area.

Sampling technique: Tempered Element Oscillating Microbalance (Model TEOM 1400ab Ambient Particulate Monitor) has been used as a standard method for continuous of PM monitoring in the AQM station. The 1400ab series TEOM (Thermo Scientific) is equivalent to US EPA method (US EPA equivalency designation number EQPM-1090-079) which provides an almost real-time $\mathrm{PM}_{10}$ masses from a 16.67, $\mathrm{lmin}^{-1}$ air flow $\left(1.002 \mathrm{~m}^{3} \mathrm{~h}^{-1}\right)$. Atmospheric air was pump though the sampling head with the flow rate of $16.67 \mathrm{lmin}^{-1}$ and then divided into filter flow $\left(3 \mathrm{lmin}^{-1}\right)$ and auxiliary flow $\left(13.671 \mathrm{~min}^{-1}\right)$.

Another pollutant such as $\mathrm{CO}, \mathrm{SO}_{2}, \mathrm{NO}_{\mathrm{x}}$ and $\mathrm{O}_{3}$ were also measured and real-time reported. Their technique, range, accuracy and their low limit detection are shown in Table 2. 
Am. J. Environ. Sci., 7 (5): 415-422, 2011

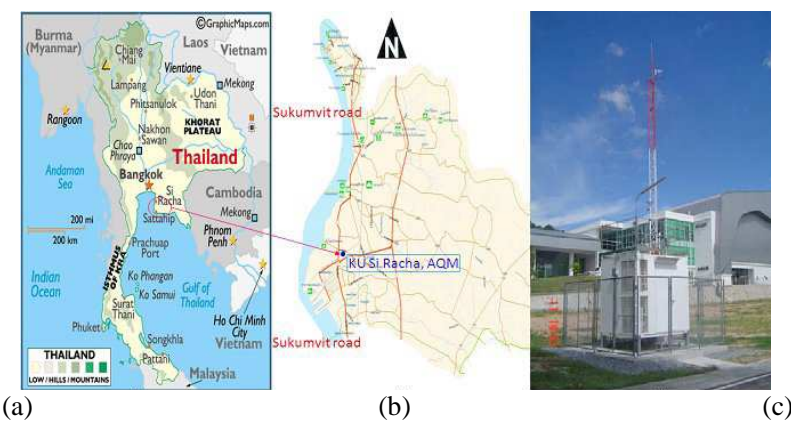

Fig. 1: The location of the sampling site (a) Chonburi province (b) Kasetsart University Si Racha Campus and (c) the Air quality monitoring station.

Table 2: Pollutants, techniques, range, accuracy and low detection limit (TEOM 1400ab data sheet)

\begin{tabular}{lllll}
\hline Pollutants analyzer & Technique & Range & Accuracy (\%) & Low limit detection \\
\hline $\mathrm{SO}_{2}$ & UV Fluorescence & $0-500 \mathrm{ppb}$ to $0-20 \mathrm{ppm}$ & 1 & $0.5 \mathrm{ppb}$ \\
$\mathrm{NO}-\mathrm{NO}_{2}-\mathrm{NO}_{\mathrm{x}}$ & Chemiluminescence & $0-500 \mathrm{ppb}$ to $0-20 \mathrm{ppm}$ & 1 & $0.5 \mathrm{ppb}$ \\
$\mathrm{CO}$ & Non-dispersive infrared detection & $0-50 \mathrm{ppm}$ to $0-200 \mathrm{ppm}$ & 1 & $0.05 \mathrm{ppm}$ \\
$\mathrm{O}_{3}$ & UV absorption & $0-500 \mathrm{ppb}$ to $0-10 \mathrm{ppm}$ & 1 & $0.5 \mathrm{ppb}$ \\
\hline
\end{tabular}

In order to measure the concentration of TSP, Teflon fiber filters were accurately pre-weighted with analytical balance (Metler Toledo AG 204 $0.0001 \mathrm{~g}$ ). Sample filters were collected from stack filter unit twicea month as located in the manifold tube with a flow rate of $\cong 1 \mathrm{~L} \mathrm{~min}^{-1}$. Meteorological data (temperature, wind speed and wind direction, dew point used to compute relative humidity data) have been provided by the facilities in the AQM station.

Chemical compositions of heavy metals analysis in particulate matters: Teflon fiber filters and a $16 \mathrm{~mm}$ PTFE-coated glass fiber filter $\left(\mathrm{PM}_{10}\right)$ were collected (twice a month) to measure the heavy metals accumulated in the particulate matter. Heavy metals adsorbed on particulate matters were determined by digesting the filter paper with $20 \mathrm{~mL}$ deionizer water (purified by Millipore Simplicity 185) in Sonorec ultrasonic bath (Super RK 514 BH). The extract solutions were analyzed by injection to inductively coupled plasma atomic emission spectrometry (ICPAES, Jobin Yvon JY2000) via nebilizingsystem (Khaenamkaew et al., 2010). The instrument was well calibrated with standard reference material (SpexCertiprep) of heavy metals.

Morphology and elemental composition analysis: The shape and physical structure of particles in the filter samples were observed using a Scanning Electron Microscope equipped with Energy Dispersive Spectrometer (Phillips: XL30 and EDAX). The filter samples were cut onto the area of $0.5 \times 0.5 \mathrm{~cm}^{2}$. Gold and carbon were coated on the filter samples with a Pirani501 device for the SEM and ED's analysis, respectively. Analytical conditions were fit to $15 \mathrm{kV}$ accelerating voltage and 100 s of effective counting time.
Besides ED's analysis, the electron beam was spot over the selected area. Elements with atomic numberless than 11 cannot be determined due to insufficient accuracy and presence of carbon in the substrate. The morphologies and spotted elemental compositions of the reference samples were shown in Fig. 7 and 8.

\section{RESULTS AND DISCUSSION}

Average concentrations of pollutants from AQM: The average concentrations of pollutants measured by AQM from July, 2007-2008 are provided in Table 3. Average concentration of ozone is higher than the standard level (100 ppb) in July 2007 and April2008 (Table 3).

$\mathrm{O}_{3}$ concentration and their possible source: Ozone is a molecule made up of three oxygen atoms $\left(\mathrm{O}_{3}\right)$, Avery reactive gasandeven at low concentrations it is irritating and toxic.

When ozone is present at ground level and in the troposphere (10-18 $\mathrm{km}$ above earth's surface), it is considered as a pollutant and a greenhouse gas (Mason et al., 2001).

The ozone concentrations are higher than the limit level in July 2007 and April 2008. Moreover, the concentrations of ozone were found relatively high in December 2007-March 2008. In this period, wind roses are indicated the ozone comes from the southwest, south and southeast direction (Fig. 2 and 3) Southern of the AQM station are the petrochemical industry and the sea side area. Ozone is readily formed in the atmosphere by the reaction of Volatile Organic Compounds (VOCs) and $\mathrm{NO}_{\mathrm{x}}$ in the presence of heat and sunlight, which are most abundant in the summer (Mason et al., 2001; Crutzen and Lelieveld, 2001). 
Am. J. Environ. Sci., 7 (5): 415-422, 2011

Table 3: Air quality and $\mathrm{PM}_{10}$ concentration from AQM

\begin{tabular}{|c|c|c|c|c|c|c|c|}
\hline Month & Average & $\mathrm{CO}(1 \mathrm{~h})$ & $\mathrm{NO}_{2}(1 \mathrm{~h})$ & $\mathrm{SO}_{2}(1 \mathrm{~h})$ & $\mathrm{O}_{3}(1 \mathrm{~h})$ & $\mathrm{PM}_{10}(24 \mathrm{~h})$ & $\operatorname{TSP}(24 \mathrm{~h})$ \\
\hline \multirow[t]{2}{*}{ Jul-07 } & Min & 0.23 & 3.9 & 0.3 & 0.6 & 18 & 54.40 \\
\hline & Max & 1.43 & 64.0 & 76.3 & 109.0 & 64 & \\
\hline \multirow[t]{2}{*}{ Aug-07 } & Min & 0.27 & 1.9 & 0.4 & 0.1 & 27 & 43.10 \\
\hline & Max & 3.08 & 52.6 & 55.8 & 7.3 & 50 & \\
\hline \multirow[t]{2}{*}{ Sep-07 } & Min & 0.78 & 0.0 & 0.0 & 0.1 & 22 & 41.30 \\
\hline & Max & 2.54 & 37.5 & 91.3 & 20.3 & 76 & \\
\hline \multirow[t]{2}{*}{ Oct-07 } & Min & 0.74 & 0.3 & 2.2 & 0.4 & 24 & 7.40 \\
\hline & Max & 2.48 & 42.2 & 41.7 & 47.7 & 114 & \\
\hline \multirow[t]{2}{*}{ Nov-07 } & Min & 0.73 & 1.3 & 2.3 & 1.1 & 24 & 9.30 \\
\hline & Max & 2.49 & 56.0 & 10.2 & 47.0 & 129 & \\
\hline \multirow[t]{2}{*}{ Dec-07 } & Min & 0.44 & 1.7 & 2.5 & 0.9 & 30 & 9.00 \\
\hline & Max & 2.31 & 66.7 & 39.4 & 91.5 & 101 & \\
\hline \multirow[t]{2}{*}{ Jan-08 } & Min & 0.55 & 0.0 & 2.6 & 1.8 & 37 & 13.80 \\
\hline & Max & 2.76 & 80.3 & 84.2 & 96.7 & 123 & \\
\hline \multirow[t]{2}{*}{ Feb-08 } & Min & 0.68 & 0.0 & 0.8 & 0.4 & 24 & 151.00 \\
\hline & Max & 2.47 & 67.2 & 62.9 & 90.2 & 100 & \\
\hline \multirow[t]{2}{*}{ Mar-08 } & Min & 0.72 & 0.0 & 0.8 & 0.0 & 29 & 9.70 \\
\hline & Max & 2.14 & 73.3 & 81.3 & 95.8 & 125 & \\
\hline \multirow[t]{2}{*}{ Apr-08 } & Min & 0.40 & 0.0 & 0.2 & 1.3 & 18 & 55.10 \\
\hline & Max & 1.70 & 40.1 & 41.7 & 114.3 & 56 & \\
\hline \multirow[t]{2}{*}{ May-08 } & Min & 0.46 & 0.6 & 0.8 & 0.4 & 21 & 8.50 \\
\hline & Max & 1.56 & 33.7 & 49.2 & 37.8 & 61 & \\
\hline \multirow[t]{2}{*}{ Jun-08 } & Min & 0.38 & 0.4 & 0.7 & 0.5 & 26 & 4.70 \\
\hline & Max & 2.27 & 47.3 & 58.1 & 47.5 & 53 & \\
\hline \multirow[t]{2}{*}{ Jul-08 } & Min & 0.00 & 0.2 & 0.8 & 0.0 & 23 & 54.40 \\
\hline & Max & 1.52 & 22.7 & 61.2 & 21.7 & 46 & \\
\hline \multicolumn{2}{|c|}{ PCD Standard unit } & $30 \mathrm{ppm}$ & $170 \mathrm{ppb}$ & $300 \mathrm{ppb}$ & $100 \mathrm{ppb}$ & $120 \mu \mathrm{gm}^{-3}$ & $330 \mu \mathrm{gm}^{-3}$ \\
\hline
\end{tabular}

\begin{tabular}{|c|c|}
\hline Wind rose & Average (\%) \\
\hline North (N) & 6.51 \\
\hline Northeast (NE) & 4.45 \\
\hline East (E) & 2.40 \\
\hline Southeast (SE) & 17.47 \\
\hline South (S) & 13.01 \\
\hline Southwest (SW) & 16.78 \\
\hline West (W) & 8.90 \\
\hline Northwest (NW) & 8.56 \\
\hline Calm & 20.50 \\
\hline
\end{tabular}

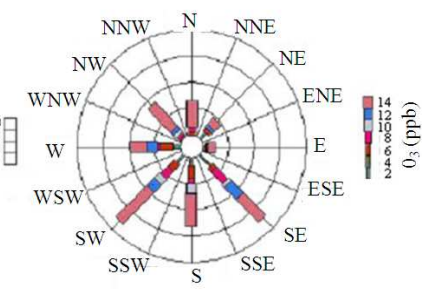

Fig. 2: The monthly pollution rose: $\mathrm{O}_{3} \max =109 \mathrm{ppb}$ in July 2007

VOCs are emitted from variety of sources, including motor vehicles, chemical plants, refineries, factories and natural (biogenic) sources (Florig et al., 2002). Nitrogen oxides (a precursor to ozone) are emitted from motor vehicles, power plants and other sources of combustion, as well as natural sources including lightning and biological processes in soil (CEPA, 2011). Figure 2 are also shown the concentration level of $\mathrm{NO}_{2}$. Although the levels are lower than standard values (170 ppb, as seen in Table 1), but the concentration are relatively high in December 2007, January 2008, February 2008 and March 2008.

Figure 2 and 3 are the wind roses of the ozone sources. In July 2007 and April 2008, the wind direction came from the southwest, south and southeast.

These result indicated that ozone possibly come from the sea spray, petrochemical industry and other factories in southern of AQM station.

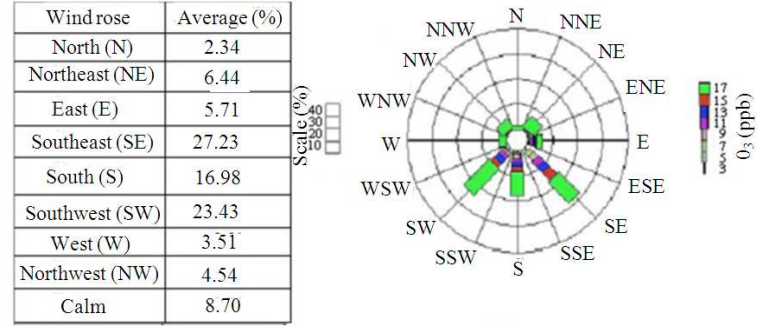

Fig. 3: The monthly pollution rose: $\mathrm{O}_{3} \max =114.3 \mathrm{ppb}$ in April 2008

$\mathrm{PM}_{10}$ concentration and their possible source: Particulate matter is the generic term for a broad class of chemically and physically diverse substances that exist as discrete particles (liquid droplets or solids) over a wide range of sizes. The concentration of TSPand $\mathrm{PM}_{10}$ are shown in Table 3. The concentrations of $\mathrm{PM}_{10}$ are higher than the limit of standard level $\left(120 \mu \mathrm{g} . \mathrm{m}^{-3}\right.$, Table 1) in November 2007, January 2008 and March 2008 with the value of 129,123 and $125 \mu \mathrm{g} \cdot \mathrm{m}^{-3}$, respectively.

Particulate matter may be emitted directly or formed in the atmosphere by transformations of gaseous emissions such as sulfur oxides, nitrogen oxides and VOCs. The chemical and physical properties of particulate matters are greatly varied with time, location, meteorology and source category, thus complicating to assessment of health and welfare 
effects (Paoletti et al., 2002). However, the wind roses of the $\mathrm{PM}_{10}$ can be also measure and carefully considered. Figure 4-6 show the wind speed and wind direction of the $\mathrm{PM}_{10}$ during the level are exceed than those standard level. November 2007 and January 2008 wind direction came from the northeast and the results indicated that $\mathrm{PM}_{10}$ possibly come from the industry estate area. While March 2008 wind direction came from the southwest direction that is transportation activity. The possible sources of particulate matter collected from this site are: commercial and residential heating, road transportation, petrochemical industry and industrial estate area. There is also a possibility that some of these airborne particulates may have migrated to this region from elsewhere (Paoletti et al., 2002).

Morphologies and elemental compositions: The surface texture of $\mathrm{PM}_{10}$ and TSP filter sample were illustrated in Fig. 7 and 8, respectively. The elemental compositions of selected $\mathrm{PM}_{10}$ and TSP were given in Table 4. Both images provided spherical particles with $10 \mu \mathrm{m}$-diameters in TSP and less than $10 \mu \mathrm{m}$ for $\mathrm{PM}_{10}$.

In agreement with the results from SEMobservations and EDS analysis (Table 4), it could be concluded that soil and rock dust represented a large proportion of particles adsorbed onto the glass and quartz filters (Han et al., 2009). Particles from anthropogenic sources and the marine environment were also found in filter samples (Khaenamkaew et al., 2010).

Chemical compositions of heavy metals in particulate matters: The amounts of selected heavy metals which were calculated in terms of mass of metals per mass of particle per unit air volume $\left(\mu \mathrm{gg}^{-1} \mathrm{~m}^{-3}\right)$. Among all metals, zinc was the most probable among all metals with the value of

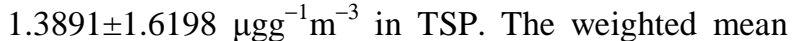
concentrations were $0.4200 \pm 0.4381,0.4293 \pm 0.5276$, $1.3891 \pm 1.6198, \quad 0.6577 \pm 0.8702$ and $0.7069 \pm 0.7186$ $\mu \mathrm{gg}^{-1} \mathrm{~m}^{-3}$ for $\mathrm{Ni}, \mathrm{Cu}, \mathrm{Zn}, \mathrm{Pb}$ and $\mathrm{Se}$, respectively. Amounts of heavy metals in $\mathrm{PM}_{10}, \mathrm{Cu}$ was dominated with $0.5374 \pm 0.8084 \mu \mathrm{gg}^{-1} \mathrm{~m}^{-3}$, the others were almost in the same levels and much lower than in TSP (Table 5). However, all of heavy metals are not exceeding than the national standard level $\left(13 \mathrm{mg} \mathrm{g}^{-1} \mathrm{~m}^{-3}\right)$ (PCD).

Correlation between amounts of $\mathbf{P M}_{10}$ and various kinds of pollutants: As mentioned in the previous paragraph, $\mathrm{O}_{3}$ and $\mathrm{NO}_{2}$ show strong correlation. It is confirmed that the $\mathrm{NO}_{2}$ is the precursor of $\mathrm{O}_{3}$ (19). Beside $\mathrm{O}_{3}$ and $\mathrm{NO}_{2}$, the strong correlation between $\mathrm{PM}_{10}$ and $\mathrm{NO}_{2}$ is shown in Table 6. It is possible that the $\mathrm{NO}_{2}$ is a precursor of $\mathrm{PM}_{10} . \mathrm{NO}_{2}$ and other chemical substances can form to be aerosol or particle-bound to water and show a particulate property.

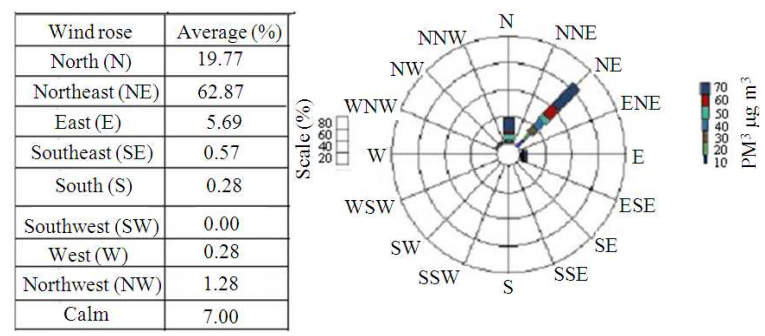

Fig. 4: The monthly pollution rose: $\mathrm{PM}_{10} \max =129 \mu \mathrm{g}$ $\mathrm{m}^{-3}$ in November 2007

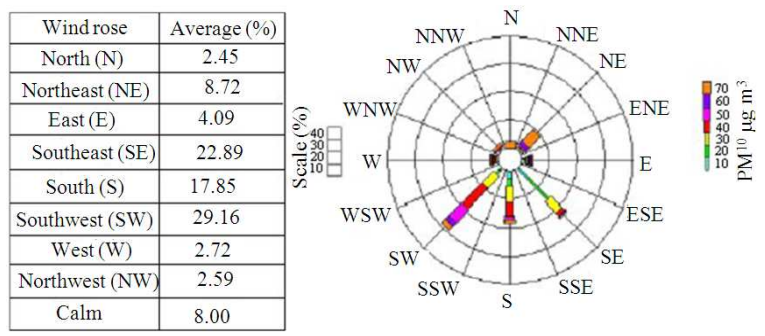

Fig. 5: The monthly pollution rose: $\mathrm{PM}_{10} \max =123 \mu \mathrm{g}$ $\mathrm{m}^{-3}$ in January 2008

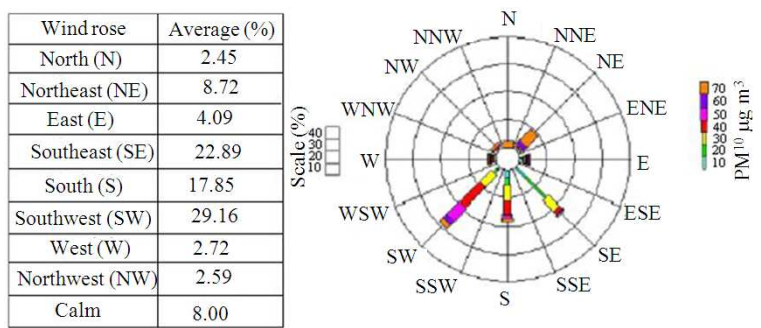

Fig. 6: The monthly pollution rose: $\mathrm{PM}_{10} \max =125 \mu \mathrm{g}$ $\mathrm{m}^{-3}$ in March 2008

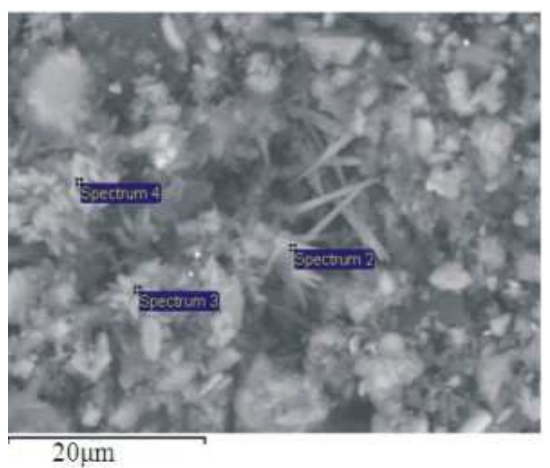

Fig. 7: SEM Micrograph of $\mathrm{PM}_{10}$ sample collected from AQM 
Am. J. Environ. Sci., 7 (5): 415-422, 2011

Table 4: Elemental composition of $\mathrm{PM}_{10}$ (spectrum 1,2 and 3) and TSP (EDS spot)

\begin{tabular}{|c|c|c|c|c|c|c|c|}
\hline \multicolumn{2}{|c|}{$\mathrm{PM}_{10}$ Spectrum 2} & \multicolumn{2}{|c|}{$\mathrm{PM}_{10}$ Spectrum 3} & \multicolumn{4}{|c|}{$\mathrm{PM}_{10}$ Spectrum 4 TSP (xEDS spot) } \\
\hline Elem & $\mathrm{Wt}(\%)$ & Elem & $\mathrm{Wt}(\%)$ & Elem & Wt (\%) & Elem & $\mathrm{Wt}(\%)$ \\
\hline C & $\begin{array}{l}19.71 \\
\end{array}$ & $\mathrm{C}$ & 22.54 & C & 28.34 & $\mathrm{C}$ & 38.60 \\
\hline $\mathrm{O}$ & 34.50 & $\mathrm{O}$ & 38.91 & $\mathrm{O}$ & 24.09 & $\mathrm{O}$ & 29.24 \\
\hline $\mathrm{Na}$ & 0.52 & $\mathrm{Na}$ & 0.71 & $\mathrm{Na}$ & 0.82 & $\mathrm{Na}$ & 2.02 \\
\hline $\mathrm{Al}$ & 1.89 & $\mathrm{Al}$ & 6.03 & $\mathrm{Al}$ & 3.61 & $\mathrm{Al}$ & 3.98 \\
\hline $\mathrm{Si}$ & 5.76 & $\mathrm{Si}$ & 19.20 & $\mathrm{Si}$ & 12.68 & $\mathrm{Si}$ & 8.99 \\
\hline $\mathrm{S}$ & 15.03 & $\mathrm{~S}$ & 2.10 & $\mathrm{~S}$ & 2.97 & $\mathrm{~S}$ & 5.00 \\
\hline $\mathrm{Cl}$ & 0.98 & $\mathrm{Cl}$ & 0.72 & $\mathrm{Cl}$ & 1.23 & $\mathrm{Cl}$ & - \\
\hline K & 1.61 & $\mathrm{~K}$ & 7.25 & $\mathrm{~K}$ & 1.87 & K & 1.80 \\
\hline \multirow[t]{5}{*}{$\mathrm{Ca}$} & 18.46 & $\mathrm{Ca}$ & 1.34 & $\mathrm{Ca}$ & 2.21 & $\mathrm{Ca}$ & 1.49 \\
\hline & & $\mathrm{Fe}$ & 1.21 & $\mathrm{Mn}$ & 1.12 & $\mathrm{Mn}$ & - \\
\hline & & & & $\mathrm{Fe}$ & 18.80 & $\mathrm{Fe}$ & 4.12 \\
\hline & & & & $\mathrm{Zn}$ & 1.44 & $\mathrm{~F}$ & 3.58 \\
\hline & & & & $\mathrm{Mg}$ & 0.80 & $\mathrm{Mg}$ & 1.18 \\
\hline
\end{tabular}

Table 5: Amounts of heavy metals in $\mathrm{PM}_{10}$ and TSP

\begin{tabular}{|c|c|c|c|c|c|c|c|}
\hline \multirow[b]{2}{*}{ PM } & \multirow[b]{2}{*}{ Collecting time } & \multirow[b]{2}{*}{ PM Weight (mg) } & \multicolumn{5}{|c|}{ Concentration of heavy Metals $\left(\mu \mathrm{gg}^{-1} \mathrm{~m}^{3}\right)$} \\
\hline & & & $\mathrm{Ni}$ & $\mathrm{Cu}$ & $\mathrm{Zn}$ & $\mathrm{Pb}$ & $\mathrm{Se}$ \\
\hline$\overline{\mathrm{PM}_{10}}$ & July 07 & 0.0739 & 0.2032 & 1.7345 & 0.6318 & 0.2422 & 0.3900 \\
\hline $\mathrm{PM}_{10}$ & October 07 & 0.0313 & 0.1874 & 0.3195 & 1.0121 & 0.1082 & 2.3122 \\
\hline $\mathrm{PM}_{10}$ & March 08 & 0.0778 & 0.1310 & 0.0587 & 0.2242 & 0.0000 & 1.0915 \\
\hline & June 08 & 0.0764 & 0.0728 & 0.0367 & 0.1859 & 0.0542 & 0.2627 \\
\hline \multicolumn{2}{|c|}{ Geometric mean } & 0.0648 & 0.1486 & 0.5374 & 0.5135 & 0.1011 & 1.0141 \\
\hline \multicolumn{2}{|c|}{ Standard deviations } & 0.0224 & 0.0593 & 0.8084 & 0.3889 & 0.1039 & 0.9390 \\
\hline TSP & July 07 & 0.0544 & 0.0773 & 0.2677 & 0.3268 & 0.1290 & 0.1280 \\
\hline TSP & August 07 & 0.0431 & 0.1350 & 0.1346 & 0.3761 & 0.3396 & 0.4523 \\
\hline TSP & September 07 & 0.0413 & 0.0509 & 0.1952 & 0.1027 & 0.3765 & 0.4837 \\
\hline TSP & October 07 & 0.0074 & 0.6303 & 0.5803 & 4.7325 & 2.6281 & 1.4313 \\
\hline TSP & November 07 & 0.0093 & 0.5615 & 0.2098 & 0.5518 & 1.6675 & 2.0320 \\
\hline TSP & December 07 & 0.0090 & 1.3053 & 1.9758 & 1.7891 & 0.8250 & 0.2861 \\
\hline TSP & January 08 & 0.0138 & 0.2313 & 0.3292 & 1.6080 & 0.2110 & 0.7866 \\
\hline TSP & February 08 & 0.1510 & 0.0253 & 0.0202 & 0.0869 & 0.0325 & 0.0494 \\
\hline TSP & March 08 & 0.0097 & 0.3852 & 0.3035 & 1.2991 & 1.6832 & 0.0000 \\
\hline TSP & April 08 & 0.0551 & 0.1047 & 0.0670 & 0.4250 & 0.0000 & 0.0000 \\
\hline TSP & May 08 & 0.0085 & 0.3218 & 0.3281 & 0.8191 & 0.0000 & 1.8210 \\
\hline TSP & June 08 & 0.0047 & 1.2116 & 0.7402 & 4.5523 & 0.0000 & 1.0124 \\
\hline \multicolumn{2}{|c|}{ Geometric mean } & 0.0339 & 0.4200 & 0.4293 & 1.3891 & 0.6577 & 0.7069 \\
\hline \multicolumn{2}{|c|}{ Standard deviations } & 0.0417 & 0.4381 & 0.5276 & 1.6198 & 0.8702 & 0.7186 \\
\hline
\end{tabular}

Table 6: The Pearson correlation between amounts of $\mathrm{PM}_{10}$ and various kinds of air pollutants

\begin{tabular}{lrrrrr}
\hline & \multicolumn{1}{c}{$\mathrm{CO}$} & $\mathrm{NO}_{2}$ & \multicolumn{1}{c}{$\mathrm{SO}_{2}$} & \multicolumn{1}{c}{$\mathrm{O}_{3}$} & $\mathrm{PM}_{10}$ \\
\hline $\mathrm{CO}$ & 1.000 & & & & \\
$\mathrm{NO}_{2}$ & 0.400 & 1.000 & & & \\
$\mathrm{SO}_{2}$ & 0.008 & 0.219 & 1.000 & & \\
$\mathrm{O}_{3}$ & -0.276 & 0.635 & 0.107 & 1.000 & \\
$\mathrm{PM}_{10}$ & 0.421 & 0.649 & -0.109 & 0.348 & 1.000 \\
\hline
\end{tabular}

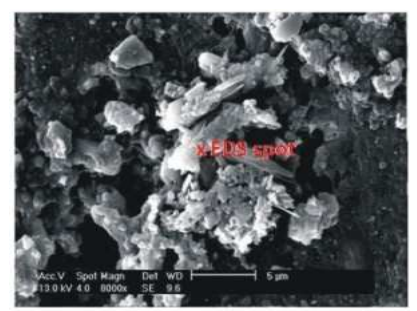

Fig. 8: SEM Micrograph of TSP sample collected from AQM
Table 7: The Pearson correlation between amounts of PM10 and various kinds of heavy metal

\begin{tabular}{lllllll}
\hline & \multicolumn{1}{c}{$\mathrm{PM}_{10}$} & $\mathrm{Ni}$ & $\mathrm{Cu}$ & $\mathrm{Zn}$ & $\mathrm{Pb}$ & $\mathrm{Se}$ \\
\hline $\mathrm{PM}_{10}$ & 1.00000 & & & & & \\
$\mathrm{Ni}$ & -0.59416 & 1.00000 & & & & \\
$\mathrm{Cu}$ & -0.24860 & $0.62924^{*}$ & 1.00000 & & & \\
$\mathrm{Zn}$ & -0.55211 & 0.71750 & 0.31973 & 1.00000 & & \\
$\mathrm{~Pb}$ & -0.46336 & 0.34170 & 0.13280 & 0.47461 & 1.00000 & \\
$\mathrm{Se}$ & -0.44293 & 0.17076 & -0.09310 & 0.25729 & 0.19705 & 1.00000 \\
\hline
\end{tabular}

Table 8: The Pearson correlation between amounts of TSP and various kinds of heavy metal

\begin{tabular}{|c|c|c|c|c|c|c|}
\hline & TSP & $\mathrm{Ni}$ & $\mathrm{Cu}$ & $\mathrm{Zn}$ & $\mathrm{Pb}$ & $\mathrm{Se}$ \\
\hline TSP & 1.00000 & & & & & \\
\hline $\mathrm{Ni}$ & -0.55904 & 1.00000 & & & & \\
\hline $\mathrm{Cu}$ & -0.42099 & $0.84587 *$ & 1.00000 & & & \\
\hline $\mathrm{Zn}$ & -0.50004 & $0.69258 *$ & 0.42457 & 1.00000 & & \\
\hline $\mathrm{Pb}$ & -0.41115 & 0.26892 & 0.16861 & 0.42615 & 1.00000 & \\
\hline $\mathrm{Se}$ & -0.51828 & 0.27292 & -0.00553 & 0.33227 & 0.33825 & 1.00000 \\
\hline
\end{tabular}


It is the secondary form of particulate matter namely artifact particulate matter (Turpin et al., 2000). Artifacts in the measurement of particle mass concentrations also arise from the adsorption of semi-volatile organic gases onto or from collected particulate matter and filter media (Tsai and Huang, 1995) and the neutralization of acid or basic gases on either filter media, or collected particulate matter (Turpin et al., 2000). Table 6 The Pearson correlation between amounts of $\mathrm{PM}_{10}$ and various kinds of air pollutants

As $\mathrm{Ni}$ is strongly correlated with $\mathrm{Cu}$ (Table 7 and 8), it may be assumed that they originated from the same source. For the TSP, the strong correlation coefficient between $\mathrm{Cu}, \mathrm{Ni}$ and $\mathrm{Zn}$ (Table 8) suggest be the same origin of these elements (Spotar and Sorokin, 2010). It could be assumed that $\mathrm{Cu}, \mathrm{Ni}$ and $\mathrm{Zn}$ partially originated from same origin due to the correlation.

\section{CONCLUSION}

The annual concentrations of $\mathrm{O}_{3}$ are higher than the limit of standard level in July 2007 and April 2008. The $\mathrm{PM}_{10}$ concentrations are higher those level in November 2007, January 2008 and March 2008. Emission sources of the $\mathrm{O}_{3}$ possibly estimate from the wind speed and wind direction. The result indicated that $\mathrm{O}_{3}$ came from the southwest, south and southeast direction where the petrochemical and others industries. $\mathrm{PM}_{10}$ came are also analyzed, the possible sources of $\mathrm{PM}_{10}$ are the industry estate and the transportation activities in SukumvitRoad. Strong correlations between $\mathrm{NO}_{2}$ with $\mathrm{O}_{3}$ and between $\mathrm{NO}_{2}$ with $\mathrm{PM}_{10}$ were found. These results show that $\mathrm{NO}_{2}$ is the precursor of the photochemical reaction and generate $\mathrm{O}_{3}$. Among the amounts of selected heavy metals, $\mathrm{Zn}$ was the most probable among all metals with the value of $1.3891 \pm 1.6198 \mathrm{ggg}^{-1} \cdot \mathrm{m}^{-3}$ in TSP. Amounts of heavy metals in $\mathrm{PM}_{10}$, $\mathrm{Cu}$ was dominated with $0.5374 \pm 0.8084$ $\mu \mathrm{g} . \mathrm{g}^{-1} \mathrm{~m}^{-3}$, the others were almost in the same levels and much lower than in TSP. The microscopic structures of TSP provided various shapes and dimensions from 0.1 to greater than $100 \mu \mathrm{m}$, while the microstructures of $\mathrm{PM}_{10}$ presented the needle-like and spherical shape. SEM-EDS analysis was able to detect some element (C, O, F, Na, Al, Si and $\mathrm{K}$ ), while the ICP-AES showed that there were other heavy metals present in the filter sample $(\mathrm{Ni}, \mathrm{Cu}, \mathrm{Zn}, \mathrm{Pb}$ and Se).Correlation coefficient between each metal can be estimate the emission source of their particulate matter together with the wind speed and wind direction.

\section{ACKNOWLEDGEMENT}

The researchers would grateful to thank Assoc. Prof. Dr. Nipon Tangkananuruk for his suggestions.
TheAQM station received the maintenance budget from Faculty of Resources and Environment. This research project was financially supported by the Kasetsart University Research and Development Institute (KURDI: Code No. RM 24.53) and partially supported by Kasetsart University, Si Racha Campus.

\section{REFERENCES}

Areekijseree, M., K. Panishkan, N. Sanmanee and K. Swangjang, 2009. Microanalysis by SEM-EDX on structure and elemental composition of soils from different agriculture areas in the western region of Thailand. J. Micro. Soc. Thai., 23: 152-156.

Baulig, A., J.J. Poirault, P. Ausset, R. Schins and T. Shi et al., 2004. Physicochemical characteristics and biological activities of seasonal atmospheric particulate matter sampling in two locations of Paris. Environ. Sci. Technol., 38: 5985-5992. DOI: 10.1021/es049476z

Brook, R.D., B. Franklin, W. Cascio, Y. Hong and G. Howard et al., 2004. Air Pollution and Cardiovascular Disease: A Statement for Healthcare Professionals from the Expert Panel on Population and Prevention Science of the American Heart Association. Circular, 109: 26552671. PMID: 15173049

CEPA, 2011. Annual monitoring network report. California Environment Protection Agency.

Crutzen, P.J. and J. Lelieveld, 2001. Human Impacts on Atmospheric Chemistry, Ann. Rev. Earth Planet Sci., 29:17-45. DOI:10.1146/annurev.earth.29.1.17

Florig, H.K., G. Sun and G. Song, 2002. Evolution of particulate regulation in China-prospects and challenges of exposure-based control. Chemosphere, 49: 1163-1174. DOI: 10.1016/S0045-6535(02)00246-1

Han, Y.M., J.J. Cao, Z.D. Jin and Z.S. An, 2009. Elemental composition of aerosols in Daihai, a rural area in the front boundary of the summer Asian monsoon. Atmos. Res., 92: 229-235. DOI:10.1016/j.atmosres.2008.10.031

Khaenamkaew, P., P. Iamraksa, S. Raksawong, K. Wongsorndham and S. Khuntong, 2010. SEM/EDS morphological and chemical composition identification of particulate matter emission from shipping activities around Si Racha Bay, Si Chang Island, Chonburi, Thailand, J. Micro. Soc. Thai., 24: 37-41.

Kim, E. and P.K. Hopke, 2008. Source characterization of ambient fine particles at multiple sites in the Seattle area. Atmos. Environ., 42: 6047-6056. DOI: $10.1016 /$ j.atmosenv.2008.03.032 
Limbach, L.K., Y. Li, R.N. Grass, T.J. Brunner and M.A. Hintermann et al., 2005. Oxide nanoparticle uptake in human lung fibroblasts: Effects of particle size, agglomeration and diffusion at low concentrations. Environ. Sci. Technol., 39: 93709376. DOI: $10.1021 / \mathrm{es} 051043 \mathrm{o}$

Mason, N., P. Hughes and R. McMullan, 2001. Introduction to Environmental Physics: Planet Earth, Life and Climate. 1st Edn., Tylor and Francis, USA., ISBN-10: 0748407650, pp: 463.

OSOS, 2009. Office of Natural Resource and Environmental Policy and Planning. One Start One Stop Investment Center.

Paoletti, L., B.D. Berardis and M. Diociaiuti, 2002. hysico-chemical characterization of the inhalable particulate matter (PM10) in an urban area: an analysis of the seasonal trend. Sci. Total Environ., 292: 265- 271. DOI: $10.1016 /$ S00489697(01)01134-2
Spotar, S.Y. and A.L. Sorokin, 2010. Focusing of the flow capture for local exhaust ventilation systems. Am. J. Applied Sci., 7: 732-738. DOI: 10.3844/ajassp.2010.732.738

Tsai, C.J. and H.Y. Huang, 1995. Atmospheric aerosol sampling by an annular denuder system and a highvolume $\mathrm{PM}_{10}$ sampler. Environ. Int., 21: 283-291. DOI: 10.1016/0160-4120(95)00024-F

Turpin, B.J., P. Saxena and E. Andrews, 2000. Measuring and simulating particulate organics in the atmosphere: problems and prospects. Atmos. Environ., 34: 2983-3013. DOI: 10.1016/S13522310(99)00501-4

Zanobetti, A., J. Schwartz and D.W. Dockery, 2000. Airborne particles are a risk factor for hospital admissions for heart and lung disease. Environ. Health Persp., 108: 1071-1077. 